\title{
Estado do Bem-Estar Social e desfiliação social
}

Alair Suzeti da Silveira'

\section{Resumo}

A partir dos anos 80, o mundo vem passando por mudanças significativas que não apenas sacralizam o mercado e satanizam o Estado, mas produzem um coletivo de desfiliados sociais, como qualificou Robert Castel. Mais do que trabalhadores sem emprego ou perspectivas de consegui-lo, trata-se de homens e mulheres "esquecidos" à margem da sociedade, como desvalidos sociais sem lugar e sem garantias cidadãs frente a um Estado cada vez mais hermético às suas responsabilidades sociais. O objetivo deste ensaio é, pois, refletir sobre a dinâmica das relações sociais de produção capitalistas e os custos sociais de um exército de esquecidos, imersos na vulnerabilidade e provisoriedade das relações cotidianas, marcadas pela hegemonia do neoliberalismo, da cultura pós-moderna e das restrições à política como prática coletiva orgânica. O desafio, neste cenário, é recuperar formas de coesão e solidariedade societal e o Estado socialmente responsável.

Palauras-chave: Estado de Bem-Estar Social. Sociedade do trabalho. Desfiliação social. Solidariedade coletiva.

\section{Introdução}

As transformações no modelo produtivo que ganharam o mundo, principalmente a partir dos anos 70 , produziram mais do que a substituição ou o hibridismo ${ }^{2}$ com relação ao modelo anterior. A profundidade das mudanças trazidas pelo modelo japonês - combinado com outros movimentos de igual

I Professora efetiva do Departamento de Sociologia e Ciência Política da Universidade Federal de Mato Grosso, Cuiabá, Brasil, é mestre em Sociologia Política pela Universidade Federal de Santa Catarina, Florianópolis, Brasil. É autora de artigos publicados nas revistas Universidade e Sociedade (Brasília, 2009). Revista de Sociologia e Política (UFPR, 2009) (Impresso), Revista Jurídica da UniRondon (200I), entre outras. É autora de obras como Sociologia jurídica - A percepção social dos direitos: instrumento legal ou de justiça social? (Juruá Editora, 2004) e A concepção e a prática democrática nas distintas classes de Cuiabá (Editora Defanti, 2000). E-mail: alairsilveira@ufmt.br.

2 Helena Hirata e outros autores compreendem que o modelo japonês, em alguns países, é assimilado de forma híbrida, preservando elementos do modelo fordista/taylorista. 
impacto, como a cultura pós-moderna, a globalização econômica e o ideário neoliberal - provocou, para além da reestruturação produtiva, o aprofundamento do desemprego, do incremento da terceirização, da precarização das relações de trabalho, do crescimento da informalidade laboral e da fragilização das entidades sindicais. Além disso, trouxe também um processo de "desidentidade" social, ou de desfiliaçâo, como define Robert Castel (2005).

A profundidade dessas transformaçóes é ainda maior quando dimensionada frente ao encolhimento das responsabilidades sociais ${ }^{3}$ do Estado e da chamada "privatização da cidadania" ‘ (DUPAS, 2005). Consequentemente, aqueles denominados "supranumerários" (CASTEL, 2005) acabam não só privados do acesso ao trabalho como tornam-se as principais vítimas desse encolhimento estatal quanto às garantias cidadás que o Estado de Bem-Estar Social - especialmente europeu - incorporou durante o período de seu apogeu.

Diante do impacto social, político e econômico dessas transformaçóes, muitas têm sido as tentativas de compreendê-las, dimensioná-las e superá-las. Nessa perspectiva, no início dos anos 2000, John Holloway provocou algumas reflexôes a partir da propositura de uma mudança civilizatória que não se estruturava sobre a tomada do poder estatal (seja de viés reformista ou revolucionário), nem na reprodução, invertida, das relaçóes cindidas entre quem elabora e manda fazer, e aos fazedores. Separação essa que, no capitalismo, segundo o autor, "se converte no único eixo de dominação" (HOLLOWAY, 2003, p. 52).

Trata-se de uma proposta que é, nos marcos das relaçôes dominantes, uma forma de antipoder", que "corresponde a um debilitamento do processo que centrou o descontentamento no Estado" (HOLLOWAY, 2003, p. 37).

3 A redução das responsabilidades sociais do Estado de Bem-Estar Social engloba desde a redução dos investimentos destinados à educação e à saúde, com sua consequente privatização ou "concorrência" com a iniciativa privada; a aplicação de políticas focalizadas, destinadas às parcelas mais vulneráveis da sociedade; e mesmo a imposição de regras que retiram do trabalhador - amparado pelo seguro social - o direito de "escolha" sobre as condições de salário e trabalho, na medida em que a recusa implica em perda do benefício.

4 De acordo com Dupas (2005, p. 177), a privatização da cidadania é produzida pela "crescente influência das lógicas organizacionais e das redes, onde o processo de dessimbolização do mundo passa a ter o economicismo e o tecnocratismo como referências centrais. [...] A crise da civilidade e a intensificação do narcisismo levam, assim, a uma emancipação do individuo de todo enquadramento normativo, a uma aversão à esfera pública e a sua consequente degradação".

5 "A luta para libertar o poder-fazer não é a luta para construir um contra-poder, mas na realidade um antipoder, algo completamente diferente do poder-sobre. [...] 0 antipoder, então, não é um contra-poder, mas algo muito mais radical: é a dissolução do poder-sobre, a emancipação do poder-fazer. [...] A tentativa de exercer o poder-fazer de uma maneira que não implique o exercício do poder sobre os outros inevitavelmente entra em conflito com o poder-sobre" (HOLLOWAY, 2003, p. 6I). 
Mais do que uma crítica às formataçóes estatais, a proposta de Holloway retoma os pressupostos anarquistas e, em certa medida, marxistas segundo os quais o Estado compóe uma engrenagem estrutural. Nessa perspectiva, a emancipação social passa pela superação do próprio Estado e não pela simples tomada do poder, com a ilusão de transformá-lo em instituição a serviço de ideais emancipatórios. Como sintetiza o autor:

O fato de o trabalho estar organizado sobre uma base capitalista significa que o que o Estado faz e pode fazer está limitado e condicionado pela necessidade de manter o sistema de organização capitalista do qual é parte. Isso significa concretamente que qualquer governo que realize uma ação significativa dirigida contra os interesses do capital terá como resultado uma crise econômica e a fuga do capital do território estatal (HOLLOWAY, 2003, p. 26-27).

A questão, entretanto, é que a superação do Estado é um propósito que não encontra substrato prático, na medida em que a complexidade societal e os processos de "invalidação"6 social demandam não a sua destruição, mas, ao contrário, sua reformulação sob a perspectiva da cidadania e da responsabilidade social.

Afinal, à medida que a sociedade se complexifica e as inovaçóes tecnológicas se expandem, como combiná-las sem transformar o mundo em um espaço de extremos que refletem reclusos e excluídos e cujo tecido social tem frágil espessura coesiva? Ou, como perspicazmente perguntou Castel: "Qual é o limiar de tolerância de uma sociedade democrática para [tolerar a] invalidação social?" (CASTEL, 2005, p. 34).

Esse é, portanto, o problema central que permeia este pequeno ensaio, não como uma tentativa de universalização da experiência europeia Pós-Guerra, mas de reflexão sobre a dinâmica das relações sociais de produção capitalistas. Relaçóes que podem expressar formas nacionais mais ou menos solidárias de cidadania e abrangência estatal, mas que no fundo guardam semelhanças nada secundárias quanto aos custos sociais dessa dinâmica, cuja face mais terrível é, justamente, o processo de invalidação social que atinge número nada desprezível de pessoas.

6 Termo utilizado por Robert Castel (2005) para caracterizar o processo de desfiliação social, que representa a imersão dos integrados no mundo dos desfiliados, que perdem suas referências de pertencimento social. 


\section{O pacto societal e os pressupostos do Estado}

A vida em sociedade não é uma tarefa fácil. Especialmente porque a adequação de múltiplos interesses e o longo aprendizado de respeito aos direitos de terceiros (na maioria das vezes, desconhecidos) exigem formas de condicionamento social que não podem ser assegurados, exclusivamente, pela força da lei e pelo recurso à violência.

Sobre essa problemática debruçou-se Émile Durkheim (1983), para quem a solidariedade social é o fundamento da vida em sociedade. Sociedades mais complexas, entretanto, demandam uma combinação de solidariedades mecânica e orgânica -, as quais permitem fundar e reproduzir a coesão social. Nesses termos, a condição para que a sociedade não se fragilize e, principalmente, náo comprometa o fundamento das suas instituiçóes ${ }^{7}$ é a solidez da coesão social.

A solidariedade mecânica, segundo Durkheim, consiste naquelas manifestaçóes de solidariedade automática, que não necessitam de vínculos de proximidade comunitária e/ou familiar - o que Castel (2005) define como sociabilidade primária - para ser estabelecida. Há, a priori, um sentimento de pertencimento social que não se restringe a grupos específicos de parentesco ou comunidade, mas atende às demandas da própria vida em sociedade, na qual - a partir de regras e valores socialmente partilhados - os indivíduos são irmanados. Esses valores socialmente partilhados constituem a base da moral coletiva (ou consciência coletiva), que permitem não somente o reconhecimento intersocial, mas a coesão social necessária à vida em sociedade.

Mais do que o ordenamento jurídico, a moral coletiva é o fundamento da unidade social. E, assim, quanto mais vigorosos forem tais vínculos morais, mais coesa será a sociedade. A sua saúde, portanto, depende da força desses vínculos de uniáo.

A solidariedade orgânica, por sua vez, depende do desenvolvimento da divisão do trabalho social e, assim, da inescapável condição de interdependência

7 Importa registrar que as instituições, para Durkheim (1983), não se restringem a organizações como Estado, empresa, familia etc., responsáveis pela unidade coletiva, mas abrangem práticas que se reproduzem e se cristalizam socialmente, fundando as bases da vida societária. Nessas condições, constituem-se em práticas "institucionalizadas", imprescindiveis para a manutenção da ordem e da estabilidade social. 
que se estabelece entre os indivíduos. Nessas condiçôes, o trabalho constitui-se em elo estruturante das relaçôes de sociabilidade.

Nesse aspecto, a centralidade da análise não está no dispêndio de energia (física e intelectual) que o indivíduo emprega para trabalhar, tampouco na dupla dimensão do trabalho, como alertava Marx, entre realização e necessidade, mas, fundamentalmente, na divisão do trabalho social que coloca todos os indivíduos em condiçóes de dependência uns dos outros, na medida em que ninguém - em sociedades desenvolvidas - é autossuficiente para produzir tudo o que consome. Obviamente que não é objeto de preocupação de Durkheim a análise das relaçóes desiguais que envolvem a produção e distribuição da riqueza socialmente produzida. Especialmente porque, segundo Durkheim, cada um tem um papel funcional para o bom andamento da sociedade.

A existência de sociedade e vínculos societais organizados em função do trabalho (necessário ao pressuposto das relaçóes de livre contrato capitalista) permite que o conjunto das relaçôes sociais gire em torno do trabalho. Assim, tê-lo ou não, ser bem remunerado ou não, ter acesso ou não ao consumo das mais variadas mercadorias, dispor ou náo de serviços de qualidade etc. remetem, necessariamente, à relação que se estabelece com o trabalho, em uma sociedade fundada sobre o trabalho.

John Locke (1983), considerado um importante filósofo político da sociedade capitalista, explicava que o pacto social que criou o Estado veio com a importante função de proteger a propriedade e a liberdade. Porém, segundo Locke, a propriedade e a liberdade estáo diretamente relacionadas ao trabalho, posto que este é o meio legítimo de adquirir propriedade; no entanto, tal dispêndio de energia física e intelectual demanda plena liberdade de iniciativa para converter-se em propriedade. Mais do que um manifesto pela liberdade, tratava-se da demanda pela manutenção da livre-iniciativa - desfrutada no estado de natureza ${ }^{8}$-, preservada da intervenção do Estado.

Observa-se aí que o trabalho constitui-se em eixo organizador da vida social, a partir do qual as relaçóes de propriedade e de poder vão sendo

8 O estado de natureza representa, segundo os autores contratualistas, aquela condição em que os homens encontram-se antes da criação do Estado. Para Locke, essa condição de liberdade e igualdade natural entre os homens, permite-lhes manifestar liuremente o "tripé": razão-trabalho-propriedade, o que permite aos liberais explicar a propriedade como um direito natural, posto que produto da inteligência e esforço individual. 
estabelecidas. Nesse sentido, Marx compreendeu que as relaçôes de propriedade dos meios de produção - do ponto de vista da imposição da dinâmica das relaçôes produtivas ${ }^{9}$ e sociais - representam, estruturalmente, a propriedade dos instrumentos de dominação que se espraiam pelo conjunto das relações infra e supraestruturais. Essas relações, entretanto, não são estanques, nem predeterminadas, mas dialéticas. Daí o caráter dinâmico das lutas de classes, entre (simplificadamente) proprietários e não proprietários. Daí, também, o inesgotável processo histórico marcado por avanços e retrocessos, involuções e revoluçôes.

Porém, enquanto Durkheim definia os vínculos coesivos como consciência ou moral coletiva, Marx os define como ideologia, a qual tem relaçáo direta com os interesses das classes dominantes. Dessa forma, se para Durkheim a moral coletiva apresenta-se como um valor social coletivo, para Marx a ideologia tem origem de classe e, nessas condiçóes, não é neutra ou universal quanto à sua origem, embora aspire universalizar-se enquanto valor socialmente partilhado.

Assim, independentemente da perspectiva teórica e política dos autores, é possível compreender que as relaçôes de trabalho fundam as bases das relações de propriedade e, como tais, as relaçôes de poder. Nesse sentido, o Estado é, inegavelmente, a principal instituiçâo "coesificadora" da vida social. Mais do que pela dupla face do seu poder, que combina força e lei, o Estado dispóe de um poder chamado irresistivel (ou de imperium), que lhe permite exercer, de forma legal e legítima, o poder coercitivo (WEBER, 1991).

Ocorre que o Estado é, antes de tudo, um poder político e, como tal, dependente de legitimidade ${ }^{10}$ social. Esse, em verdade, é o seu Calcanhar de Aquiles, posto que mesmo o poder de imperium náo lhe assegura o poder absoluto de mando sem sérios riscos para a estabilidade política. Não por acaso,

9 Trata-se, aqui, de compreender que as explicações de Marx quanto à propriedade dos meios de produção não se restringem à mera propriedade destes, mas à identificação daqueles que, enquanto classe dominante, imprimem a dinâmica das relações produtivas. E a atuação como classe implica em compreender seu caráter econômico e político e não somente proprietário.

10 O conceito de legitimidade utilizado é aquele elaborado por Weber (1991), para quem a legitimidade é uma prerrogativa daquele (ou daqueles) que está na condição subalterna de uma determinada relação e, nessa condição, confere - ou não - a essa relação a qualificação de "justa", independentemente do fundamento racional pelo qual tal qualificação seja orientada. Afinal, como também ensina Weber, a racionalidade não representa verdade/razão absoluta, universal ou metafísica, mas decorre das relações objetivas nas quais os individuos estão inseridos e, a partir das quais, elaboram seus "fins subjetivamente visados". 
Maquiavel (1999) já alertava sobre a necessidade de o Príncipe (governante) ser amado (legitimado) pelo povo para não temer a todos os lugares e todas as circunstâncias.

A questão crucial, entretanto, é que o reconhecimento da importância do Estado náo implica em desprezar a necessidade de compreender a fonte de legitimidade dos governos e dos parlamentos, cujos poderes decorrem - em regimes democráticos - da vontade majoritária dos eleitores.

Se, por um lado, o Poder Executivo e o Legislativo resultam do sufrágio popular, por outro, as motivaçóes eleitorais que se expressam no processo de escolha têm vários matizes. Especialmente porque os eleitores organizam suas preferências eleitorais a partir das informaçóes de que dispóem, as quais, combinadas às condiçôes desiguais de disputa, tornam o processo eleitoral um instrumento democrático ${ }^{11}$ com inúmeros déficits democráticos.

É sobre essa relação estreita entre Estado e sociedade (que é, também, de interdependência) que Claus Offe (1984) analisa, a partir da perspectiva marxista, os recursos que o Estado utiliza para conquistar legitimidade social e, assim, transformar, discursivamente, em interesse coletivo o que é interesse particular.

Segundo Claus Offe, o regime democrático é aquele em que mais eficientemente o Estado consegue cumprir sua dupla função: realizar a valorização do capital e, simultaneamente, ocultá-la. De um lado, o Estado vale-se dos chamados filtros ${ }^{12}$, que lhe permitem convencer a sociedade sobre o caráter social das políticas particulares que implementa; de outro, vale-se do sufrágio popular para justificar decisóes que favoreçam o capital, como decisóes de corresponsabilidade social, na medida em que sejam aprovadas previamente no processo eleitoral, com a eleição dos seus representantes. O regime

II A democracia pressupõe, dentre outras coisas, não apenas a isonomia de tempo e espaço para a apresentação das propostas em disputa, mas, também, que o poder econômico não interfira no processo de escolha. Essas condições são sistematicamente ignoradas. A discussão sobre a Reforma Política e Eleitoral, que tramita no Congresso Nacional brasileiro há anos, continua a centrar suas energias nas listas (fechada ou aberta), no financiamento (público, privado ou misto), na fidelidade partidária e na cláusula de barreira; porém, não reflete sobre as condições absolutamente desiguais em que os partidos chamados "nanicos" participam das campanhas eleitorais. Dessa forma, fecha-se o círculo que mantém partidos grandes com grande representação parlamentar e os partidos "nanicos" eternamente marginais.

12 Offe (1984) classifica-os como: I) Socioestruturais; 2) Ideológicos; 3) Processuais; e 4) Repressivos. 
democrático dispõe, ainda, da possibilidade de administração dos conflitos sociais, canalizando a indignação popular para as eleições seguintes.

Dessa forma, o pacto social que se estabelece entre sociedade e Estado, pautado pela confiança entre cidadáos e entre estes e o Estado, depende da relação de "justeza" (na perspectiva weberiana) que aqueles que estão na condição de governados atribuem àqueles que estão na condição de governantes. Para conquistar tal legitimidade, vários recursos são utilizados e, obviamente, eles são tanto mais eficazes quanto mais conseguirem transformar, discursivamente, interesses particulares em interesses coletivos.

A coesão social, portanto, está diretamente relacionada à capacidade dos vínculos societais de manterem relaçôes de confiança, previsibilidade e reciprocidade, tanto entre os cidadáos, quanto entre estes e o Estado. Para tanto, é preciso que o Estado atue como uma instituição que promova o bem-estar das maiorias, de forma a satisfazer o maior número e, assim, obter a legitimidade de que precisa. Porém, as questóes que envolvem, objetivamente, as relaçóes de poder entre interesses antagônicos não respondem simplesmente à observação do princípio democrático do maior número, mas decorrem da correlação de forças entre aqueles que são em maior número e aqueles que, em menor número, detêm condiçôes estruturais favoráveis que lhes permitem valer-se de um leque de recursos capazes de atenuar a força do número pela competência do discurso ${ }^{13}$, que transforma interesses particulares em interesses públicos e, assim, submete sem necessitar fazer uso da força.

Por consequência, nos marcos da institucionalidade, a conquista do poder do Estado é uma condição fundamental para definir os rumos das políticas estatais, tendo em vista que governar é estabelecer prioridades, as quais se encontram sujeitas ao projeto de sociedade que os partidos dominantes (na perspectiva gramsciana) defendem. Daí por que o conhecimento do projeto de sociedade que orienta o programa partidário (confrontado com a prática partidária) é fundamental no processo eleitoral ${ }^{14}$.

13 Expressão de Marilena Chaui (1989) - Cultura e Democracia: o discurso competente e outras falas.

14 Especialmente se nas condições isonômicas exigidas pela Democracia e, também, em ambientes de debates efetivos, onde os candidatos objetivamente confrontam propostas, posições e contradições. Os atuais debates ocorridos no Brasil são sintomáticos da tentativa de assepsia política, que impede o confronto e a tudo limita em nome de regras convenientemente acordadas por assessores políticos que, assim, impedem o debate e o desvendamento de candidaturas que, muitas vezes, nada mais são do que diferentes siglas defendendo o mesmo projeto de sociedade. 
Os chamados 30 anos gloriosos (1945-1975) expressaram a combinação entre boom econômico e vontade política. Às condições subjetivas após a Segunda Guerra Mundial, assim como à ameaça "comunista", conjugaram-se a recuperaçáo econômica e, principalmente, as experiências governativas da social-democracia ${ }^{15}$, especialmente europeia. É o que Castel denomina de estado de crescimento, isto é, crescimento econômico e crescimento do Estado social.

O Estado de Bem-Estar Social que emergiu - e consolidou-se - nesse período é, portanto, resultado de decisão política com crescimento econômico ${ }^{16}$. Afinal, na medida em que a social-democracia conquistou o poder do Estado, passou a implementar os fundamentos programáticos - do ponto de vista político $^{17}$ - quanto ao reconhecimento da legitimidade das organizaçóes coletivas, tanto do trabalho quanto do capital. A social-democracia partilha, junto com os socialistas, da concepção de sociedade classista, o que significa reconhecer que, estruturalmente, entre capital e trabalho há conflitos antagônicos. Porém, diferentemente dos socialistas, a social-democracia defende reformas dentro da ordem capitalista e, nesse sentido, atribui ao Estado o importante papel no sentido de harmonizar tais conflitos, agindo como árbitro, de forma a manter a ordem econômica e social. Nessa perspectiva, a social-democracia consagra grande importância à democracia progressiva e, ao mesmo tempo, ao protagonismo estatal.

Esse protagonismo, entretanto, não se fez à revelia das organizaçôes coletivas; efetivamente, demandou participação na riqueza socialmente produzida e ampliação de direitos coletivos, universalizados. A centralidade da experiência social-democrata está justamente no fato de reconhecer legitimidade às

15 Embora nos Estados Unidos a social-democracia não seja uma referência com força política, também lá plantou suas raizes, através do New Deal. E, como afirmou Tony Judt: "Os anos 1945-1975 foram considerados quase milagrosos, na opinião da maioria, dando origem ao American way of life. Duas gerações de americanos - homens e mulheres que passaram pela Segunda Guerra Mundial e seus filhos, que celebrariam os anos 1960 - desfrutaram de segurança no trabalho e ascensão social numa escala sem precedentes (e que jamais se repetiria)" (JUDT, 2011 , p. 56).

16 Porém, como alerta Castel, o crescimento econômico não representa a condição sine qua non para a existência do Estado de Bem-Estar Social: "O crescimento facilitou as coisas, mas não substitui a vontade política. Esquece-se, aliás, com frequência, de lembrar que, sem dúvida, a abertura mais decisiva em matéria de direitos sociais foi realizada com a Seguridade Social em 1945 e 1946, numa França devastada e cuja produção havia caído aquém do limiar atingido em 1929" (CASTEL, 2005, p. 502).

17 Do ponto de vista econômico, a social-democracia amparou-se, largamente, na teoria keynesiana, de inspiração liberal. Vê-se, então, que não por acaso a social-democracia é considerada um caminho alternativo entre o Liberalismo e o Socialismo. 
organizaçóes coletivas (tanto do capital quanto do trabalho) e, dessa forma, interagir com tais organizaçóes, estabelecendo com elas uma interlocuçáo democrática.

\section{A "falência" do Estado de Bem-Estar Social e o individualismo anticoletivo}

A apreensão do impacto das transformaçóes ocorridas a partir dos anos 70 implica em compreender as particularidades das relaçôes envolvidas, em suas múltiplas e combinadas expressóes. Primeiramente porque uma sociedade fundada sobre o trabalho converteu-se em uma sociedade marcada pela escassez e/ou precariedade de trabalho; em segundo lugar, porque os valores societais baseados na solidariedade foram esgarçados, a ponto de produzir relaçóes de aparente anomia (para utilizarmos um conceito durkheimeano); em terceiro lugar, porque o individualismo ultrapassou qualquer referência de singularidade e direito civil para avançar para manifestaçóes abertamente egoístas e socialmente excludentes; em quarto lugar, porque a redução do papel do Estado restringiu-se às suas responsabilidades sociais, mas não alcançou suas estreitas relaçóes de patrocínio ao capital; em quinto lugar, porque o discurso que envolve a globalização econômica, apresentando-a como inexorável, adéqua-se perfeitamente à orfandade política decorrente da derrocada do Leste Europeu e a consequente sentença de morte que acompanhou qualquer projeto político e social alternativo ao capitalismo; em sexto lugar, porque o sentimento de impotência e indiferença política se ajusta perfeitamente à cultura pós-moderna, com sua apologia ao relativismo, à bricolagem explicativa, à emotividade e ao individualismo, além da efemeridade das relaçóes e das imagens; em último lugar, porque o ideário neoliberal não somente criminaliza os movimentos sociais, senão que condena o Estado Social e as políticas de caráter universalizante pela crise econômica e de "governabilidade".

Consequentemente, a crise vivenciada pelo Estado de Bem-Estar Social não decorre de um fenômeno localizado e pontual, mas de uma combinação explosiva de movimentos que convergem para uma retraçáo da política como exercício coletivo intra e extrainstitucional, que promove a contraçáo do estatuto da cidadania, seja como gozo do direito ao trabalho, seja como garantia do direito à seguridade social universal. 
Assim, se o período de 1945 a 1975 representou o apogeu do Estado de Bem-Estar Social e, com ele, a consolidação democrática nos países centrais e o "pleno" emprego, o período que lhe deu sequência representa o seu contrário. Afinal, como questiona Tony Judt: "O que a confiança, a cooperação, a taxação progressiva e o Estado intervencionista legaram às sociedades ocidentais nas décadas seguintes a 1945?” Pergunta que, de forma resumida, o próprio autor responde: "[...] em vários graus, segurança, prosperidade, serviços sociais e mais igualdade" (JUDT, 2011, p. 75).

Mas se esse foi o legado, como é possível compreender "a tolerância de uma sociedade democrática para com a invalidação social", como questionou Castel (2005)? A resposta, dentre outras coisas, deve ser buscada no que Dejours (1999) classifica como banalização do mal ${ }^{18}$. Para esse autor, a adesão (generalizada) à causa economicista permite uma dissociaçáo entre adversidade e injustiça e, consequentemente, uma tolerância para com o infortúnio e sofrimento de milhares de concidadáos ${ }^{19}$. Nas suas palavras:

[...] há uma clivagem entre sofrimento e injustiça. Essa clivagem é grave. Para os que nela incorrem, o sofrimento é uma adversidade, é claro, mas essa adversidade não reclama necessariamente reação política. Pode justificar compaixão, piedade ou caridade. O sofrimento somente suscita um movimento de solidariedade e de protesto quando se estabelece uma associação entre a percepção do sofrimento alheio e a convicção de que esse sofrimento resulta de uma injustiça (DEJOURS, 1999, p. 19).

Se a adversidade é associada à dor particular (e circunstancial) do 'outro', e a injustiça a um ferimento que ofende, primeiro, aos pressupostos da moral coletiva e, assim, demanda reação política, a grande questão que se coloca é como revitalizar os laços de solidariedade social em uma sociedade cada vez mais individualista e refratária às açôes políticas coletivas.

Tem-se, assim, que o desinteresse pela política e pelas questóes de interesse público, por parcelas cada vez mais expressivas da sociedade, comporta mais

18 Amparando-se no conceito desenvolvido por Hannah Arendt, Dejours (1999) promove sua releitura ajustando-o às manifestações contemporâneas de experiência do mal e sua consequente tolerância social.

19 O autor sublinha que a separação entre adversidade e injustiça "não resultaria, como se costuma crer, da mera resignação ou da constatação de impotência diante de um processo que nos transcende, mas funcionaria também como uma defesa contra a consciência dolorosa da própria cumplicidade, da própria colaboração e da própria responsabilidade no agravamento da adversidade social" (DEJOURS, 1999, p. 21). 
do que geraçóes avessas aos problemas de relevância coletiva. Implica na consagração de jovens e adultos cada vez mais devotados às questóes particulares e à exposição (ou acompanhamento) da vida privada como forma de prestígio social $^{20}$. Nessa perspectiva, o público como expressão de interesse coletivo é esvaziado de sentido e passa a representar, tão somente, hiperexposição. E nessa condiçấo, quanto mais invasiva for a exposição da privacidade pessoal ou alheia, consentida ou usurpada, mais ela conquista atenção. Como observou Bauman (2000, p. 71):

[...] o "público" foi despojado de seus conteúdos diferenciais e ficou sem agenda - não passa agora de um aglomerado de problemas e preocupações privados. É uma colcha de retalhos de anseios pessoais por ajuda para dar sentido a emoções e estados de espírito privados ainda inarticulados, por instruções sobre como falar dessas emoções em linguagem que os outros entendam e por conselho sobre como lidar com a série de experiências que os indivíduos acham tão difíceis de encarar. A lista de "questões públicas" não difere da de "questões pessoais" nem aquela é mais rica que a "soma das parcelas".

Paradoxalmente, essa colcha de retalhos - tão adequada à cultura pós-moderna - serve de base para as inúmeras manifestaçôes de individualismo exacerbado que perfazem o homo economicus neoliberal. Ao elevar a emoção como parâmetro organizacional de várias relações contemporâneas ${ }^{21}$, os interesses particulares alforriam-se das exigências solidárias que a vida societária impóe como padrão comportamental (moral coletiva).

Nessas condiçốes, o agir econômico e o agir social interagem não sob a forma do utilitarismo econômico, a partir do qual o interesse individual promove o bem coletivo, mas promove o interesse individual como valor

20 Tony Judt registrou seu assombramento com o fascínio que a desigualdade social tem provocado em amplas parcelas sociais: "Uma coisa é viver em meio à desigualdade e suas patologias; outra bem diferente é se alegrar com elas. Por toda parte há uma propensão escandalosa à admiração da extrema riqueza e ao consentimento com seu status de celebridade" (JUDT, 20II, p. 33).

21 A escola, por exemplo, tem sido um espaço institucional onde o apelo às emoções tem ganhado força cada vez maior. Em respeito ao ritmo de aprendizado do estudante, implantaram-se as aprovações automáticas, que aprovam sem avaliar; em nome da sensibilidade estudantil, o caráter educativo da escola foi sendo esvaziado de sentido; para não ofender os alunos, os professores devem evitar corrigi-los em sala de aula; em virtude das pessoalidades, as avaliações devem ser mais "abertas", aceitando as formas de expressão e manifestação do aluno; para não traumatizar o estudante, produzindo preconceito linguístico, a escola deve tolerar outras formas de manifestação que não sejam aquelas para as quais foi criada; e, com o propósito de transformar a aula em ambiente atraente aos estudantes (adeptos da vitimação e do imagético), a densidade acadêmica deve ser substituida por aulas "criativas". Esses são apenas alguns dos exemplos atuais da política educacional predominante, não somente no Brasil. 
social ${ }^{22}$. Porém, as consequências da retração política e do individualismo exacerbado comprometem, também, as bases da sociedade democrática. Não somente porque a democracia requer igualdade de direitos e liberdades, independente de traços pessoais e suscetibilidades, mas porque o princípio da maioria pressupóe a sujeição individual à vontade majoritária - o que pode parecer contrapor-se ao idealismo individualista, que se ressente de qualquer disciplina coletiva que cerceie a irrestrita liberdade pessoal. Afinal,

Esse mundo novo é o da crescente influência das lógicas organizacionais e das redes, onde o processo de dessimbolização do mundo passa a ter o economicismo e o tecnocratismo como referências centrais. [...] A crise da civilidade e a intensificação do narcisismo levam, assim, a uma emancipação do indivíduo de todo enquadramento normativo, a uma aversão à esfera pública e a sua conseqüente degradação. [...] geram a progressiva privatização da cidadania (DUPAS, 2005, p. 177).

A passagem, segundo Dupas (2005, p. 175), de uma sociedade política para uma sociedade organizacional tem como consequência a fragmentação e a proliferação de identidades coletivas particulares, parciais e truncadas, as quais acentuam diferenças que, muitas vezes, impedem o reconhecimento das semelhanças. Consequentemente, a identidade forjada sobre a particularidade e a diferença fragiliza ainda mais as condições de enfrentamento político, especialmente em condiçóes estruturalmente desiguais.

Dessa forma, a matriz monológica ou dialógica ${ }^{23}$ (OFFE; WIESENTHAL, 1984) que orienta, respectivamente, a ação coletiva do capital e do trabalho

22 Considerando a história recente, especialmente brasileira, é possivel perceber as transformações ideológicas que acompanharam a percepção social sobre o lucro capitalista. Se durante um período ele era referenciado com certo pudor, posto que era claramente associado à exploração dos trabalhadores (efeito da atuação das organizações coletivas e das teorias classistas), com o passar do tempo, o lucro passou a ser reverenciado não somente como objetivo legítimo, mas como um valor em si mesmo.

23 Claus Offe e Helmut Wiesenthal valem-se dos conceitos de lógica monológica e lógica dialógica para explicar as condições desiguais de organização coletiva, que se estendem das condições objetivas para as condições subjetivas. Segundo os autores, os empresários dispõem de uma unidade ideológica fundamental, posto que se beneficiam da lógica do capitalismo para fundar suas organizações e difundir seus interesses, lógica que envolve não somente empresários mas, inclusive, os próprios trabalhadores. Estes, por sua vez, para se organizarem, precisam negociar a lógica que interessa ao capital (na qual se encontram imersos e tornam-se, muitas vezes, defensores) e a lógica que interessa ao trabalho. Esse processo dialógico, entretanto, não é realizado de forma tranquila e evolutiva, posto que a organização coletiva do trabalho depende do número de membros para contrapor-se ao peso do capital, porém, quanto maior o número de filiados, maior é o universo dialógico necessário ao estabelecimento de ações unitárias e coesas (OFFE; WIESENTHAL, 1984). 
é agravada ainda mais severamente pela fragmentação de coletivos fundados sobre especificidades, cuja identidade de classe é secundarizada, ou simplesmente rejeitada.

Essas condiçôes adversas - inclusive subjetivas ${ }^{24}$ - às formas de organizaçáo e intervençáo coletiva trazem suas consequências tanto para as relaçóes de trabalho, quanto para o exercício democrático institucional. De um lado, porque a democracia requer mais do que igualdade jurídica: ela demanda um sentimento de irmandade, tolerância e cultura democrática (BOBBIO, 1992) que não pode consolidar-se sobre o esgarçamento do sentimento de pertencimento social e o esfarelamento das formas de solidariedade coletiva. De outro, porque em uma sociedade construída sobre a valorização do trabalho, a escassez de trabalho, o fosso entre estáveis e vulnerávei ${ }^{25}$ e outras formas de precarização das relaçóes laborais, além do desemprego crônico, comprometem os vínculos associativos e solidários necessários à intervenção social.

Assim, se do ponto de vista laboral pode-se refletir sobre a fragilização das entidades sindicais, desafiadas a recriar formas de organizaçáo que consigam reproduzir a eficácia do passado diante de um presente abertamente refratário às açôes coletivas, seja pelo individualismo exacerbado, pelos supranumerários, pela rejeição à política ou pela banalização do mal... também é possível refletir sobre o esvaziamento que essa combinaçáo nefasta provoca nos regimes democráticos.

Sob o ponto de vista das relaçóes de trabalho, há, ainda, a sedução provocada pelo modelo japonês ${ }^{26}$, que capturou não apenas a força física do trabalhador, mas a sua subjetividade, como perspicazmente analisou Ricardo Antunes. Nessas condiçóes, náo somente convenceu o trabalhador sobre a superação da separação entre elaboração e execução, convocando-o às

24 Como já foi destacado anteriormente, o ideário neoliberal (que é, ainda, hegemônico) criminaliza as organizações coletivas, especialmente dos trabalhadores. Corroborando tal ideário, o discurso da globalização econômica apregoa a inexorabilidade do processo em nivel mundial e esvazia de perspectiva as ações coletivas nacionais. Tais ideários articulam-se às condições subjetivas, em um processo retroalimentar que reforça a causa economicista e a consequente adesão social.

25 Combinação do fosso identificado por Ricardo Antunes (1995): estáveis e precários; e Castel (2005), que reconhece a vulnerabilidade como uma condição que espreita a todos, sejam aqueles que já estão vulneráveis (expulsos do mercado), sejam aqueles que podem vir a sê-lo a qualquer momento.

26 A apresentação das características centrais dos modelos fordista/taylorista e toyotista (japonês) foi feita em trabalho anterior, dedicado exclusivamente a este fim (SILVEIRA, 2008). 
reunióes participativas, a partir das quais se apropria do seu conhecimento intelectual sem remunerá-lo por isso; mas, convenceu-o de que agora, ao invés de trabalhador, seu status estava elevado à condição de colaborador polivalente (ANTUNES, 1995).

Capturada sua subjetividade, o modelo o persuadiu sobre a "modernidade" dos sindicatos por empresa e das negociaçóes individuais, sob o argumento de que as negociaçóes sindicais coletivas massificam as particularidades de cada um e desrespeitam as individualidades. Assim, dedicados a demarcar seus diferenciais para obter créditos negociais, os trabalhadores competem e fiscalizam-se entre si, e voltam as costas aos sindicatos. Como decorrência, aumentam a produtividade patronal e fragilizam suas entidades representativas.

Dessa forma, e paradoxalmente, a consolidação e o espraiamento de regimes democráticos pelo mundo (inclusive na América Latina, a partir dos anos 1980) ocorrem em pleno período de apologia ao individualismo e retraçáo da política como expressão intra e extrainstitucional. Consequentemente, consagra-se uma democracia - inclusive nos países centrais - muito mais restrita aos processos eleitorais do que às intervençóes coletivas com capacidade de interferir nas esferas decisórias. Daí a pertinência da pergunta de Jacques Gènèreux (1999, p. 19): "Se não soubermos nos mobilizar para defender nossos empregos, como vamos saber nos levantar para defender a democracia, quando ela não for mais que uma palavra sem conseqüência concreta em nossas vidas?"

Nesse sentido, se a política é rejeitada como instrumento de ação coletiva, também a reflexão sobre relevância do Estado é relegada ao ostracismo. Mais do que isso: há uma espécie de apagamento dos vestígios ${ }^{27}$ (DEJOURS, 1999) do Estado de Bem-Estar Social ${ }^{28}$, de forma a permitir que o ideário de

27 Conceito desenvolvido por Dejours para destacar os recursos utilizados no mundo do trabalho, não somente para "omitir os fracassos, [...] encobrir os acidentes de trabalho, pressionando os empregados a não os denunciarem, [...] sonegar informações sobre os incidentes que afetem a segurança das instalações ou [...] disfarçá-los sucessivamente. Consiste, também, ao que parece, em apagar a lembrança de práticas do passado que possam servir de referência à comparação crítica da época atual" (DEJOURS, 1999, p. 66).

28 Nas palauras de Judt (20II, p. 66-67): "Nas três décadas seguintes à Guerra, os economistas, políticos, analistas e cidadãos concordaram que os gastos públicos volumosos, administrados por autoridades nacionais ou locais, com considerável margem para regulamentar a vida econômica em vários níveis, era uma boa política. Vozes discordantes eram consideradas resquícios pitorescos de um passado esquecido - ideólogos fanáticos por teoremas fantasiosos - ou defesa de interesses privados que se colocavam acima do bem-estar público. O mercado tinha seu lugar, o Estado garantia um papel central na vida das pessoas, e os serviços sociais 
satanização do Estado e sacralização do mercado reine absoluto, sem vestígios de memória que sejam capazes de pôr em xeque os fundamentos do neoliberalismo hegemônico.

Assim, embora a discussão não seja exatamente contrapor Estado versus mercado, como ensinou Kurz $(1997)^{29}$, não é possível negligenciar as implicaçóes quanto ao tamanho do Estado e do mercado, tendo em vista que é sobre essa equação que os projetos de sociedade se estruturam e, nessa condição, são implementados quando alcançam o poder do Estado, por meio dos partidos governantes. Nesse sentido, o desinteresse social pela política e a desinformação que envolve os processos eleitorais têm como consequência, na maioria das vezes, a prevalência de projetos de sociedade que são, na prática, socialmente excludentes.

Mas se o poder originário, em sociedades democráticas, pertence ao cidadão, por que esse cidadão tolera governantes que impóem como perspectiva societária a exclusão de amplas parcelas sociais e o mantêm em permanente condição de vulnerabilidade?

Daí a complexidade que envolve a democracia. Afinal, mesmo respeitados os pressupostos elementares - minimalistas ${ }^{30}$, como define Bobbio (1992) - , tais garantias não asseguram que a vontade dos cidadãos seja produto do seu acesso às informaçóes necessárias e ao debate público que a democracia pressupóe. É preciso que o elo que liga os cidadáos entre si e o elo destes com o Estado sejam alimentados pelo sentimento de pertencimento e responsabilidade social. E é nesse sentido que o esgarçamento da moral coletiva atua diretamente sobre o exercício democrático, especialmente porque, na democracia, as decisóes particulares têm consequências públicas.

tinham prioridade sobre outras despesas do governo [...] Como isso aconteceu? Mesmo admitindo que as metas e práticas coletivas fossem em princípio admiráveis, hoje elas seriam consideradas ineficazes [...] - e de todo modo perigosas, passiveis de se tornarem instrumentos econômicos e sociais de 'burocratas', 'politicos' $e$ 'governo central"'.

29 Robert Kurz destaca que o Estado exerce funções econômicas necessárias ao desenvolvimento do capital e, nesse sentido, a oposição entre Estado e Mercado é equivocada, na medida em que eles "constituem os dois pólos de um mesmo 'campo' histórico da modernidade" (KURZ, 1997, p. 93). Com esse argumento, Kurz apresenta os seguintes niveis de intersecção: $1^{\circ}$ ) Jurídico; $2^{\circ}$ ) Problemas sociais e ecológicos; $3^{\circ}$ ) Agregados infraestruturais; $4^{\circ}$ ) Atividade estatal empresarial; $5^{\circ}$ ) Politicas de subsidios e protecionismo.

30 A definição minimalista (ou procedimental), segundo Bobbio (1992), exige o estabelecimento de regras claras sobre quem, quantos, onde e sob quais procedimentos e condições os titulares do poder originário exercem a vontade soberana, assim como quem está autorizado a tomar decisões em nome dos titulares. 
A desvalorização da democracia traz como consequência, por sua vez, a desconsideração da política (persuasão/convencimento) como instrumento para resoluçáo dos conflitos. Da mesma forma como multiplica o número de cidadáos cada vez mais individualistas e indiferentes aos tormentos e infortúnios dos seus concidadáos. Reflexo da violência da calma, como bem definiu Viviane Forrester (1997), ao retratar o processo de indiferença generalizada e solidariedade fugaz que marca as sociedades contemporâneas com relaçáo à escassez de emprego e ao crescimento do número de inúteis para a exploraçáo do trabalho.

O círculo vicioso que alimenta o individualismo é o mesmo que alimenta a violência da calma e o desapego à democracia como regime político capaz de ser utilizado para produzir as mudanças socialmente ansiadas. Como questiona Généreux (1999, p. 19): "Quantos não chegarão a pensar que, se a democracia acarreta o desemprego, a insegurança e a miséria, não seria nada mal trocar um pouco menos de democracia por um pouco mais de bem-estar material cotidiano?".

Atílio Boron (2001), na contracorrente da ideologia dominante que se apropriou da democracia condicionando sua existência ao liberalismo (como é caso de Bobbio, por exemplo), é taxativo ao demonstrar a incompatibilidade entre a lógica liberal do Mercado e a lógica da Democracia, e, assim, a excepcionalidade de harmonia entre ambos. Consequentemente, nas sociedades liberais, a democracia acaba subsumida à lógica do mercado. De acordo com Boron (2001), enquanto a democracia genuina é ascendente, includente, expansiva e animada pelo afä de justiça, o mercado, por sua vez, é descendente, seletivo, privatista e animado pela busca incessante do lucro.

Nessas condiçóes combinadas e retroalimentadas, que reclamam a "falência" do Estado do Bem-Estar Social e promovem a privatização da cidadania (DUPAS, 2005) - ou descidadanização, conforme Boron (2001) - há um processo mais perverso sendo gerado: aquele que Castel (2005) define como desfiliaçâa social.

\section{Sociedade do trabalho e desfiliação social}

A desfiliação social representa um processo de desprendimento da vida social. Náo como resultado de uma escolha pessoal, mas como "destino" de 
um movimento que foge às determinaçôes individuais, posto que decorre de deliberaçôes relacionadas à própria dinâmica de desenvolvimento do capital. Trata-se, como observa Castel (2005, p. 32), daqueles que, mais do que excluidos, foram "abandonados, como se estivessem encalhados na margem, depois que a corrente das trocas produtivas se desviou deles".

Se o atual estágio de desenvolvimento do capitalismo - denominado acumulação com dominância financeira (CHESNAIS, 2003) - é marcado pela predominância do capital financeiro e especulativo sobre o capital produtivo, do ponto de vista produtivo sua sujeição às demandas do mercado ${ }^{31} \mathrm{e}$ o alto grau de desenvolvimento tecnológico lhe permitem prescindir de um número significativo de trabalhadores para desenvolver-se, gerando, assim, o que Castel (2005) classifica como supranumerários e Forrester (1997) como inuiteis. Logo, se antes o grande desafio era como integrar plenamente a todos, a questão agora, segundo Castel (2005, p. 33), é "amenizar sua presença, torná-la discreta a ponto de apagá-la”.

O resultado desse processo, segundo Ricardo Antunes, é o espetáculo da guerra, destruição, precarização, eliminação de postos de trabalho, desemprego estrutural, num mundo cuja "razão instrumental" é o pleno exercício da "desrazão" (VASAPOLLO, 2004, p. 11).

Caracterizados como supranumerários, inúteis, excluídos, desfiliados, vulneráveis, desvalidos sociais, inadaptáveis, residuais, banidos, rejeitados do crescimento, precários, "gangrena do pauperismo" etc., esses trabalhadores descartáveis pelo desenvolvimento econômico sobrevivem à margem da sociedade que não lhes reconhece a injustiça, da qual fala Dejours. Vítimas de invalidação social, eles têm o "provisório como modo de existência" (CASTEL, 2005, p. 543).

Essa provisoriedade que, sob todos os aspectos, expõe a condição de vulnerabilidade na qual parte significativa de trabalhadores (empregados ou não) está imersa representa o lado contemporâneo de uma sociedade fundada sobre os valores do trabalho, mas cuja capacidade de absorção qualificada pelo trabalho, assim como de amparo digno pelo Estado, é duplamente corroída. Como argutamente observou Forrester (1997, p. 14):

31 Trata-se de um modelo que, diferentemente do fordismo/taylorismo, tem uma dinâmica que primeiro capta a demanda para, depois, produzir; enquanto que naquele, o movimento era da indústria para o mercado, apoiando-se na publicidade para promover a necessidade e o consumo. 
Continuamos com rotinas bem estranhas! Não se sabe se é cômico ou sinistro, por ocasião de uma perpétua, irremovível e crescente penúria de empregos, impor a cada um dos milhões de desempregados - e isso a cada dia útil de cada semana, de cada mês, de cada ano - a procura "efetiva e permanente" desse trabalho, que não existe.

A questáo, portanto, é compreender como o processo de invalidação e desfiliação social vai sendo tecido, a partir das transformaçôes que se processam no mundo do trabalho. Primeiro porque, para além da mudança no perfil do trabalhador em razão do desenvolvimento das forças produtivas e do modelo produtivo, há, também, mudanças no processo produtivo.

As mudanças no perfil laboral apontam, dentre outras coisas, para a feminilização da força de trabalho, a redução significativa de trabalhadores empregados na indústria e, em compensação, o crescimento do emprego no setor comercial e de serviços. Essas mudanças, entretanto, não representam a manutenção ou o incremento das conquistas salariais e das condiçôes de trabalho. Primeiro porque a força de trabalho feminina é aquela que, preferencialmente, é absorvida para os chamados trabalhos parciais ou precários, cujos salários têm dupla fonte de contenção: o preconceito de gênero e a precarização desses vínculos empregatícios. Em segundo, porque o aumento da oferta de trabalho no comércio e no serviço não compensa o número de excluídos da indústria e, além disso, representa faixas salariais significativamente inferiores àquelas conquistadas nas indústrias, por onde se construiu boa parte da história sindical dos trabalhadores (ANTUNES, 1995; POCHMANN, 2001).

Quanto às mudanças no processo produtivo, a combinaçáo da nova divisão internacional do trabalho com a deslocalizaçáo produtiva tem permitido o aprofundamento das condiçóes de invalidaçáo. Segundo Vasapollo (2004, p. 36), “[...] a deslocalização da produção em direção a países cujos níveis salariais são baixos [...] [provoca] um novo colonialismo com formas de marginalização absolutas".

Esse movimento não apenas "universaliza" as formas de exploração mundial, mas provoca, simultaneamente, tanto a contraçáo das demandas salariais e sindicais nos países de origem e nos receptores, quanto agrava o quadro de desemprego, precarização das relaçôes de trabalho e desfiliação social nos países de origem. Como sintetiza Vasapollo (2004, p. 35): 
Some-se a isso a notável transformação dos processos produtivos, que tem levado à necessidade de passar de um uso elevado de mão-de-obra (trabalho intensivo) para um modelo dito industrial, baseado no capital material (implantes e ferramentas, capital intensivo) e no aumento dos custos destinados ao capital imaterial (informação, pesquisa e desenvolvimento).

Esse quadro, embora generalizado, náo é vivenciado da mesma forma pelos países capitalistas centrais e pelos países periféricos ${ }^{32}$, tendo em vista que a chamada "nova" divisão internacional do trabalho promove uma "polarização entre a produção de manufatura, em parte dos países semiperiféricos, e a produção de bens industriais de informação e comunicação sofisticados e de serviços de apoio à produção, gerada no centro do capitalismo" (POCHMANN, 2001, p. 34).

Consequentemente, as condiçóes de empregabilidade nos setores que agregam mais valor ao trabalho e, por decorrência, aos termos de troca internacional permanecem concentradas nos países centrais, apesar de o discurso da globalizaçáo econômica reiterar o ganho generalizado a todos que aderirem às regras do jogo.

Assim, a expansão mundializada do capital não representa a internacionalização das condiçôes salariais e de trabalho dos países centrais para as demais regiôes do planeta, mas, ao contrário, a periferização das relaçóes salariais e de trabalho nos países centrais. Ou, como ironizou Ricardo Antunes (1995), "[...] a mundialização do toyotismo não representa, como sugere CORIAT, a social-democratização do toyotismo, mas, a toyotização da social-democracia".

Nesse aspecto, inclusive, a desigualdade social que sempre marcou os países periféricos também foi absorvida pelos países centrais como parte desse processo de periferização. Estudos recentes demonstram que no Reino Unido a diferença salarial entre funcionários e executivos, em 2010, era de 145 vezes; enquanto o salário da média da população subiu 7,2\% de 1998 a 2008, o dos mais ricos subiu 64\% (MARINHEIRO, 2011, p. A19). A situação não é diferente em outros países. Nos Estados Unidos, por exemplo,

32 Como observa Pochmann (200I, p. 14), “[...] apesar de encontrar-se subordinada ao desenvolvimento das atividades produtivas, a capacidade de absorver uma maior ou menor quantidade de trabalhadores não depende exclusivamente do grau de expansão de cada país, mas do padrão de desenvolvimento nacional e de sua forma de inserção na economia mundial". 
[...] a diferença nos ganhos dos muito ricos e dos pobres atingiu níveis não vistos desde a Grande Depressão (anos 30). Pesquisas têm mostrado que enquanto os salários e bônus dos executivos americanos quadruplicaram desde os anos 1970, a renda de 90\% dos trabalhadores do país estagnou no período. Em muitos casos as empresas que financiaram a explosão dos pagamentos a executivos reduziram os salários dos empregados comuns (MURTA, 2011, p. AI4).

Logo, esse quadro de periferização das condiçôes materiais de existência, trabalho e remuneraçãa ${ }^{33}$ do trabalhador médio nos países centrais representa um processo de corrosão da sociedade salarial, como denominou Castel (2005, p. 580):

Uma formação social que havia conseguido esconjurar, em grande parte, a vulnerabilidade de massa e assegurar uma ampla participação nos valores sociais comuns. Em outros termos, a sociedade salarial é o alicerce sociológico em que se baseia uma democracia do tipo ocidental, com seus méritos e suas lacunas; não a justiça social, mas o controle e a redução da arbitrariedade dos ricos e dos poderosos; não o governo de todos, mas a representação de todos os interesses e sua apresentação para debate no cenário público.

Consequentemente, o esfacelamento da sociedade salarial revela mais do que a perda de um padrão societário baseado na solidariedade e na seguridade social; revela, também, uma sociabilidade corroída pelo esforço de sobrevivência e/ou preservação, cujo medo de proletarização (como alertava Marx sobre a classe média) é, atualmente, ainda mais grave, pois pode representar vulnerabilidade bem superior.

Essa vulnerabilidade social é amplamente perceptível a partir do que Boaventura de Sousa Santos define como "crise da contratualização moderna, decorrente da predominância estrutural dos processos de exclusão sobre os de inclusão" (SANTOS, 199, p. 45). Segundo o autor, a exclusão apresenta-se "sob duas formas, na aparência, contraditórias: o pós-contratualismo e o pré-contratualismo".

O primeiro representa a exclusão de grupos e interesses sociais até agora incluídos no contrato social [...] sem qualquer perspectiva de regresso; já o pré-contratualismo consiste no bloqueamento do acesso à cidadania por parte de grupos sociais que anteriormente se

33 Nas palauras de Castel (2005, p. 478): “A condição de assalariado não é só um modo de retribuição do salário, mas a condição a partir da qual os indivíduos estão distribuídos no espaço social. [...] o assalariado é julgado-classificado por sua situação de emprego, e os assalariados encontram seu denominador comum e existem socialmente a partir deste lugar". 
consideravam candidatos à cidadania e tinham expectativa fundada de a ela aceder (SANTOS, 1999, p. 48-49).

Essa crise do contrato moderno carrega consigo o que Boaventura define como fascismo societal, que, segundo ele, não é “[...] um regime político, mas antes de tudo um regime social e civilizacional. [...] Trata-se de um fascismo pluralista e, por isso, uma forma de fascismo que nunca existiu" (SANTOS, 1999, p. 51).

Segundo o autor,

Este fascismo pluralista se expressa através de seis tipos: a) Fascismo do apartheid social, que implica na segregação social dos excluídos através de uma cartografia urbana dividida em zonas selvagens e zonas civilizadas; b) Fascismo do Estado paralelo, que consiste em um duplo padrão de ação estatal nas zonas selvagens e nas zonas civilizadas; c) Fascismo paraestatal, que manifesta-se através da usurpação de prerrogativas estatais (de coerção e de regulação social) por parte de atores sociais muito poderosos, muitas vezes com a conivência do próprio Estado, que ora neutralizam ora suplementam o controle social produzido pelo Estado [por meio de] duas vertentes principais: o fascismo contratual e o fascismo territorial; d) Fascismo populista, expresso pela democratização do que na sociedade capitalista é indemocratizável, através de dispositivos de identificação imediata como forma de consumo e estilos de vida que estão fora do alcance da maioria da população; e) Fascismo da insegurança, o qual é alimentado pela manipulação discricionária da insegurança das pessoas de grupos sociais vulnerabilizados pela precariedade do trabalho, ou por acidentes ou acontecimentos desestabilizadores, produzindo-lhes elevados níveis de ansiedade e de insegurança quanto ao presente e ao futuro, de modo a fazer baixar o horizonte de expectativas e a criar disponibilidade para suportar grandes encargos, de modo a obter reduções mínimas dos riscos e da insegurança; f) Fascismo financeiro, o qual representa, provavelmente, a forma mais virulenta de sociabilidade fascista. Este é o fascismo que comanda os mercados financeiros de valores e de moedas, a especulação financeira [...]. Por ser mais pluralista é também o fascismo mais virulento, pois seu tempo-espaço é o mais refratário a qualquer intervenção democrática (SANTOS, 1999, p. 51-57).

Tem-se, assim, que o fascismo societal que atravessa o conjunto das relaçôes sociais, mantendo unidade quanto ao processo de exclusão daqueles que ficam encalhados nas margens, transforma a vulnerabilidade em um sentimento constante em amplos segmentos da sociedade. E, como toda forma de fascismo, não alimenta solidariedade como vínculo societário, posto que o fascismo é um regime discricionário que só tolera aqueles considerados "seus iguais". Daí porque a existência de zonas de reclusão e exclusão social, que 
demarcam geograficamente os incluídos e os excluídos, deixa na zona de risco e de incerteza uma parte considerável daqueles que, embora ainda incluídos, temem resvalar para as zonas selvagens.

Nesses marcos sociabilizatórios, a questão recorrente é como equacionar o desequilíbrio social e econômico, mas também moral e político, entre uma sociedade que sobrevive fundada sobre a valorização do trabalho e uma realidade que não produz trabalho suficiente ${ }^{34}$ para absorver a todos. E como garantir vida social digna àqueles que, sem trabalho, também passam a depender de um Estado cada vez mais enxuto do ponto de vista das suas responsabilidades sociais $^{35}$. Isto é, como abdicar de um Estado de Bem-Estar Social que recobre o estatuto da cidadania com a universalidade dos direitos e garantias civis, em nome de um Estado que retoma as clássicas atribuiçôes liberais: defesa externa, garantia de cumprimento dos contratos e segurança interna. Embora esta, agora, seja "concorrente" com a iniciativa privada em boa parte dos países.

Afinal, se o número de desfiliados cresce em proporção impressionante, assim como o número daqueles que, mesmo com trabalho, não ganham o suficiente para a reprodução da própria força de trabalho e de seus familiares, também é do Estado a responsabilidade por manter - em sociedades democráticas - o controle social através de políticas focalizadas, dedicadas às populaçóes vulneráveis (nos marcos da agenda neoliberal). Ocorre, porém, que o custo de tais programas assistenciais é extraído das receitas do Estado, o qual, sob a hegemonia neoliberal, ao mesmo tempo em que contrai suas responsabilidades sociais, expande suas políticas de subsídios e isenções ao capital.

O surpreendente desse processo de involução dos valores sociabilizatórios fundados sobre a solidariedade e a coesão social é que boa parte das geraçóes atuais naturalizam a exclusão como parte da vida social, assim como a existência

34 Obviamente que não se está, aqui, desconhecendo que a mera existência de trabalho não implica em qualidade nas condições e remuneração do trabalho capazes de assegurar uma vida digna, mas acentuar que a falta de trabalho, nos marcos de uma sociedade estruturada sobre a valorização do trabalho, atormenta os desempregados, que se sentem responsáveis (envergonhados, como alerta Forrester) pela própria exclusão e acabam por desenvolver patologias e sentimentos de inferioridade e autoexclusão convivial.

35 A discussão sobre a aprovação, pelo parlamento estadunidense, da elevação do teto da dívida pública (em 2011) é expressiva das prioridades políticas que envolvem as relações de poder relativas ao tamanho do Estado social: de um lado, um Congresso de maioria republicana, que condiciona a aprovação à redução dos gastos nos programas sociais; de outro, um governo democrata que desloca a fonte de cortes para as isenções fiscais que beneficiam as grandes fortunas, assim como o aumento de impostos sobre os mais ricos. 
de um Estado não integrador socialmente, restrito às políticas assistenciais, focalizadas nos segmentos invalidados. E, mesmo assim, muitos se ressentem dos gastos reservados a esses segmentos, caracterizados como parasitas sociais e, no melhor estilo neoliberal, preguiçosos que querem aproveitar-se da boa vida assegurada pelo Estado, às custas daqueles que trabalham. Esse é um argumento que expressa claramente o comprometimento do princípio da solidariedade social e geracional que orientou as principais políticas sociais do Estado de Bem-Estar Social.

Como ponderou Judt (2011, p. 91), as geraçôes posteriores àquelas que viveram os horrores da Guerra e que se beneficiaram dos frutos do Estado de crescimento não partilham as mesmas referências que organizaram as geraçóes predecessoras: "O consenso implícito das décadas do Pós-Guerra se rompera, e um consenso novo, decididamente artificial, começava a emergir em torno do interesse particular”. De forma amarga, registra o autor:

\begin{abstract}
A "identidade" passou a colonizar o discurso público: identidade privada, identidade sexual, identidade cultural. Daqui à fragmentação da política radical e sua metamorfose em multiculturalismo foi um passo curto. Curiosamente, a nova esquerda permaneceu sensível aos atributos coletivos dos humanos que residiam em terras distantes, onde podiam ser reunidos em categorias sociais anônimas como "camponeses", "pós-coloniais", "subalternos” e assim por diante. Em casa, porém, o indivíduo reinava supremo (JUDT, 20 I I, p. 89).
\end{abstract}

Se o individualismo é o soberano, como é possível reverter o processo de desfiliação social, que exige a indignação coletiva contra a injustiça e a banalização do mal (DEJOURS, 1999)? É essa indiferença pelo sofrimento alheio, violento e calmo, apoiada na adesáo à causa economicista, que permite que mesmo em sociedades democráticas seja possível suportar a desfiliação dos outros sem esboçar reaçôes coletivas. Como sensivelmente sintetizou Forrester (1997, p. 36-37):

[...] nos apressamos em esquecer que cada um deles está desesperadamente inscrito num nome, numa consciência, embora nem sempre num "domicílio fixo". Cada um é prisioneiro desse corpo a alimentar, abrigar, cuidar, fazer existir e que incomoda dolorosamente. [...] Esse olhar tão velho que a miséria incrusta até nos rostos jovens, até nos bebês. [...] Olhares ainda mais insustentáveis quando, como acontece, neles ainda sobrevive alguma espera. Não há pior angústia que a esperança. Pior tremor. E não há pior horror que o fim de si próprio quando ocorre bem antes da morte e se deve arrastar enquanto vivo. [...] Esses rostos, esses corpos de pessoas que não parecem mais pessoas [...] ainda se considerando 
ou se lembrando da pessoa que foram, de que se encarregaram ou pensaram encarregar-se, têm consciência do que se tornaram.

É neste sentido que a pergunta impertinente de Viviane Forrester (1997, p. 17) assume maior pertinência: "E se acontecesse de não estarmos mais numa democracia?" Afinal, mesmo tendo a democracia, majoritariamente, se restringido ao exercício eleitoral, ainda assim ela permite avaliar as manifestações mais inorgânicas ${ }^{36}$ que a sociedade expóe e, consequentemente, em democracias consolidadas; essas manifestaçôes são entendidas como "recados" de insatisfação social ${ }^{37}$ quanto aos rumos das políticas estatais.

Desse modo, e dentro da institucionalidade, apesar dos limites da democracia eleitoral, este ainda é o melhor regime para produzir as mudanças necessárias para a inclusão de todos, como observou Boron. Entretanto, para isso é preciso que as bases do "darwinismo" social e da descrença política sejam superadas. É preciso, como alertavam Hirst e Thompson (1998), que o "mito da globalização" inexorável, que a tudo avassala e condiciona, seja desconstruído, permitindo a reapropriação da capacidade de intervenção política nacional.

Mas para recuperar o protagonismo da cidadania é preciso, também, recuperar o papel soberano do Estado. Refundar as bases da sua responsabilidade social e resgatar a consciência coletiva e os pressupostos inclusivos do contrato social.

Paradoxalmente, em um período em que se reclamam os direitos coletivos difusos e - implicado nesta lógica - o reconhecimento da terra como espaço

36 As redes virtuais, associadas como expressão de wikidemocracia, que têm tido grande visibilidade nos últimos tempos (especialmente a partir da Revolução Árabe e das várias formas espontâneas de convocação política), têm sido apontadas como forma de substituição das formas orgânicas de participação e intervenção política, especialmente frente à desconfiança que cerca os partidos políticos e as formas tradicionais de representação política. Essas redes virtuais, entretanto, apresentam sérios problemas quanto à consequência das mobilizações sociais, pois não dispõem de organização política orgânica capaz de oferecer um projeto político e social para mobilizar seus membros para sua implantação. Em decorrência, são eficientes para provocar a derrubada de um regime ou de um governo (como nas experiências recentes), mas dissolvem-se após sua vitória. Dessa forma, sua eficácia ainda depende da combinação com formas orgânicas de intervenção política. A experiência egípcia é apenas a ilustração mais recente.

37 O movimento dos Indignados, constituido por jovens europeus desempregados reclamando o emprego que lhes foi prometido - e que, em grande medida, é recusado sob a justificativa da última crise financeira -, reivindica mais do que emprego, exige democracia real já!, o que demonstra profunda descrença nas formas tradicionais de representação política. 
comum ao conjunto da humanidade, as formas de exclusão social converteram-se em problema social de grande envergadura. Esse paradoxo, entretanto, parece responder muito mais a uma perspectiva egoísta de autopreservação do que a uma forma solidária de preservar os demais. De certa maneira, sob uma forma aparentemente generosa, reproduz-se a violência da calma. Mesmo que, embutida nessa discussão ambiental, esteja a retomada da soberania coletiva, emprestada ao Estado e por ele usurpada, dedicado à defesa inconteste da propriedade privada. Nas palavras de Mares (2003, p. 248):

A introdução de uma propriedade coletiva volta a pôr em discussão a soberania do povo porque, por um lado, quebra a soberania individual da propriedade privada e por outro reconhece direito a uma coletividade que, sendo soberana, novamente empresta ao Estado para ser defendida, fazendo ressurgir a necessidade de um ente estatal capaz de exercer a proteção da soberania do povo e não da soberania individual.

Nesse contexto mundial de retração do emprego e do crescimento das zonas de vulnerabilidade - onde as solidariedades coesificadoras do tecido social são esgarçadas porque condicionadas à lógica da antipolítica e do individualismo exacerbado -, o processo de desfiliação é um processo em aberto, porém ascendente.

E essa desfiliação, mais do que um desprendimento das zonas de integração - ou, nas palavras de Boaventura Santos, de pós-contratualismo -, representa um caminho cuja volta à integração social demanda o retorno da política como recurso central, de forma a recuperar - ou construir, no caso dos países periféricos - o Estado de Bem-Estar Social. Assim, se no contexto da mundialização do capitaß ${ }^{8}$ (CHESNAIS, 2003) a deslocalização da produção rompeu com a filiação social que perfazia os vínculos societários que, inicialmente, organizavam as relaçóes de trabalho e reconhecimento coletivo, é necessário que essa deslocalização não represente o banimento (CASTEL, 2005) da integração de coletivos inteiros pela exclusão do acesso ao trabalho.

38 Se a globalização econômica reflete os movimentos do capital no sentido de consolidar uma "aldeia global" fundada sobre a lógica - e os interesses - do capital, a mundialização do capital, segundo Chesnais (2003), compreende não somente esses movimentos, mas revela suas consequências e demandas do ponto de vista da sociedade civil. Para Chesnais, essa condição de domínio do capital - manifesta especialmente a partir dos anos 80 - combina mudanças quantitativas e qualitativas, sob a égide da financeirização. Dessa forma, a "mundialização" beneficia-se, de um lado, do acúmulo de capital e, de outro, da política neoliberal, que ataca não somente o Estado Social, mas as conquistas sociais e democráticas. Consequentemente, segundo Chesnais (2003), é preciso construir instituições políticas mundiais capazes de dominar esse movimento. 


\section{5. À guisa de conclusão}

Se, como destaca Josep Picó, o Estado de Bem-Estar Social foi construído sobre o excedente econômico produzido pelo capitalismo, ele teve de se ajustar às suas leis, especialmente por meio da construçẫo de um consenso político, nos limites dos pressupostos capitalistas. Daí a incompatibilidade de duas lógicas distintas, destacada por Boron, porém contestado por Picó. De acordo com esse último autor:

Así pues, fundado sobre el excedente económico y el consenso político, y restringido por la lógica y el funcionamiento de las instituciones capitalistas y democráticas, el Estado del Bienestar tiene el efecto de contribuir a la reconciliación entre capitalismo y democracia. Por ello el impacto del Welfare sobre la estructura social es ambivalente, y mantiene tanto las tendencias igualitarias como las de preservación del estatus (PICÓ, 1999, p. 135).

O problema, entretanto, é que a lógica da preservação do status em detrimento das tendências igualitárias foi esgarçada ao limite com a escassez de trabalho em plena vigência de uma sociedade estruturada sobre os valores do trabalho. Nessas condiçôes, o individualismo antipolítico e imagético ${ }^{39}$ contribui para fortalecer os mecanismos de indiferença, traduzidos pela violência da calma.

Porém, a história é sempre uma oportunidade em aberto. E apesar daqueles que chegaram a decretar seu fim, a história permanece como um caminho a ser percorrido, cujas trajetórias podem levar a lugares diversos. Daí porque a compreensão sobre as condiçôes subjetivas não pode ser subsumida às condiçōes objetivas, posto que, apesar da desfiliação crescente, das manifestaçóes xenófobas, do aumento da desigualdade social ${ }^{40} \mathrm{e}$ das formas de retraçáo

39 A cultura pós-moderna que rejeita as metateorias enaltece a imagem e a estética em detrimento da densidade e do conteúdo, e faz apologia da volatibilidade do tempo e das relações, é a mesma que contribui para (des) ensinar e desaprender a pensar. "Porque não há nada mais mobilizador do que o pensamento. [...] Não existe atividade mais subversiva do que ele. Mais temida. Mais difamada também. [...] o pensamento é político. [...] Só o fato de pensar já é político. Dai a luta insidiosa, cada vez mais eficaz, hoje mais do que nunca, contra o pensamento. Contra a capacidade de pensar." (FORRESTER, 1997, p. 67-68).

40 Em entrevista ao jornal Folha de S. Paulo, o professor Evilásio Salvador (UnB) observou que a "eliminação da pobreza extrema pode ocorrer só estatisticamente se os beneficiários dos programas sociais não tiverem acesso a trabalho, educação, saúde e previdência social". Ainda de acordo com o Professor, os mais pobres bancam dois terços do que o governo gasta com programas que os beneficiam: "os tributos que financiam a seguridade social incidem, em grande parte, sobre o faturamento e as receitas das empresas, que acabam repassando para o consumo. Com isso, $62 \%$ das fontes de financiamento da seguridade são tributos indiretos, que oneram os mais pobres, que são os beneficiários dos programas sociais" (Folha de S. Paulo, 13 mar. 20II, p. AII). 
política, há um contramovimento coletivo que tem demonstrado a insatisfação com o rumo da vida social.

Nesse sentido, mais do que a consideração sobre a eficácia ou não de tais movimentos de resistência social, há que se atentar para o conteúdo das manifestaçôes que reclamam transformaçôes macropolíticas, econômicas e sociais. Afinal, nesse aspecto, envolvem uma perspectiva social ampliada, na medida em que reivindicam mudanças que são socialmente inclusivas.

As manifestaçôes iniciadas em Seattle contra a globalização econômica excludente, assim como as revoltas árabes, os movimentos dos jovens europeus desempregados, a resistência dos gregos, ou mesmo a participação virtual da sociedade islandesa para redação da sua nova Constituição, são demonstraçôes da retomada - mesmo que lenta - descontínua e contraditória da consciência social do próprio protagonismo e, neste sentido, da desconfiança nas formas de representação tradicional.

Como perspicazmente observou Picó (1999):

Ahora bien, como he señalado ya en ocasiones anteriores, el welfare State há supuesto una serie de transformaciones y cambios en la sociedad actual difíciles de olvidar o suprimir; ha cambiado y extendido muchos de los derechos individuales y colectivos al bienestar social, ha modificado las formas de la conflictualidad sociopolítica, ha visto nacer nuevos grupos y frentes de reivindicación, ha extendido el concepto de democracia, y todo esto ha reformulado la dialéctica Estado-sociedad (PICÓ, 1999, p. 140).

Castel (2005), de certa forma, manteve abertas as condiçóes para o reencontro entre a economia e a política, a reintegração e as responsabilidades sociais do Estado. Afinal, por mais esforços que o liberalismo tenha feito no sentido de separar o ente econômico do ente político, as consequências das decisóes políticas se refletem na economia, assim como estas se refletem na política.

É sob a perspectiva das "ondas longas" (nos mesmos moldes da análise econômica) que é possível compreender que, apesar do esvaziamento do caráter público das responsabilidades coletivas e da sua substituição pela espetacularização do privado, da privatização da cidadania e do esgarçamento das formas de solidariedade social que coesionam a sociedade, a desfiliação social não é um destino padrasto.

Talvez, mais do que nunca, seja necessário refletir sobre a sugestáo de Holloway (2003, p. 68-69) para que "[...] em lugar de começar com múltiplas 
identidades [...], precisamos começar com o processo de identificação que as gera”. Ou, como reclama Forrester (1997, p. 142), é preciso superar o movimento que se restringe a "fechar o jornal que está lendo, desligar o televisor".

$\mathrm{Ou}$, ainda, quem sabe, diante deste cenário de vulnerabilidade que a todos envolve, em maior ou menor medida, refletir sobre a atualidade - e as consequências - da servidão voluntária desvendada por La Boétie no século XVI:

De onde tirou tantos olhos com os quais vos espia, se não os colocais a serviço dele? Como tem tantas mãos para golpear-vos, se não as toma de vós? Os pés com que espezinha vossas cidades, de onde the vem senão dos vossos? Como ele tem algum poder sobre vós, senão por vós? Como ousaria atacar-vos se não estivesse conivente convosco? Como poderia fazer-vos se não fôsseis receptadores do ladrão que vos pilha, cúmplices do assassino que vos mata, e traidores de vós mesmos? (LA BOÉTIE, 1999, p. 16).

\section{Referências}

ANTUNES, Ricardo. Adeus ao trabalho? - Ensaio sobre as metamorfoses e a centralidade do mundo do trabalho. 2. ed. São Paulo: Cortez; Campinas, SP: Editora da Universidade Estadual de Campinas, 1995.

BAUMAN, Zygmunt. Em busca da política. Tradução de Marcus Penchel. Rio de Janeiro: Jorge Zahar, 2000.

BOBBIO, Norberto. O futuro da Democracia: em defesa das regras do jogo. Tradução de Marco Aurélio Nogueira. 5. ed. São Paulo: Paz e Terra, 1992.

BORON, Atílio A. Os "novos leviatâs” e a pólis democrática: neoliberalismo, decomposição estatal e decadência da democracia na América Latina. In: SADER, Emir; GENTILI, Pablo. (Org.). Pósneoliberalismo II: que Estado para que democracia? 3. ed. Petrópolis, RJ: Vozes, 2001.

CASTEL, Robert. As metamorfoses da questáo social: uma crônica do salário. Tradução de Iraci D. Poleti. 5. ed. Petrópolis, RJ: Vozes, 2005.

CHAUÍ, Marilena. Cultura e Democracia: o discurso competente e outras falas. 4. ed. Rev. e Ampl. São Paulo: Cortez, 1989.

CHESNAIS, François. A "Nova Economia": uma conjuntura própria à potência econômica Estadunidense. In: CHESNAIS, François et al. Uma nova fase do capitalismo? Tradução de Andréia Galvão e José Marcos Nayme Novelli. São Paulo: Xamã, 2003.

DEJOURS, Christophe. A banalizaçáo da injustiça social. Traduçấo de Luiz Alberto Monjardim. 2. ed. Rio de Janeiro: Fundação Getúlio Vargas, 1999. 
Estado do Bem-Estar Social e desfiliação social | Alair Suzeti da Silveira

DUPAS, Gilberto. Atores e poderes na nova ordem global: assimetrias, instabilidades e imperativos de legitimação. São Paulo: Editora da UNESP, 2005.

DURKHEIM, Émile. As regras do método sociológico. São Paulo: Abril Cultural, 1983. Coleção Os Pensadores.

A função social da divisáo do trabalho. São Paulo: Abril Cultural, 1983. Coleção Os Pensadores.

FORRESTER, Viviane. O horror econômico. Tradução de Álvaro Lorencini. São Paulo: Editora da UNESP, 1997.

GÈNÈREUX, Jacques. O horror político - O horror não é econômico. Tradução de Eliá Jacobina. 2. ed. Rio de Janeiro: Bertrand-Brasil, 1999.

HIRST, Paul; THOMPSON, Grahame. Globalização em questáo: a economia internacional e as possibilidades de governabilidade. Tradução de Wanda Caldeira Brant. Petrópolis, RJ: Vozes, 1998.

HOLLOWAY, John. Mudar o mundo sem tomar o poder: o significado da revolução hoje. Tradução de Emir Sader. São Paulo: Viramundo, 2003.

JUDT, Tony. O mal ronda a terra: um tratado sobre as insatisfaçóes do presente. Tradução de Celso Nogueira. Rio de Janeiro: Objetiva, 2011.

KURZ, Robert. A falta de autonomia do Estado e os limites da política. In: Os últimos combates. Petrópolis, RJ: Vozes, 1997.

LA BOÉTIE, Etienne de. Discurso da servidáo voluntária. Tradução Laymert Garcia dos Santos. São Paulo: Brasiliense, 1999.

LOCKE, John. Segundo tratado sobre o governo. Tradução de Anoar Alex e E. Jacy Monteiro. São Paulo: Abril Cultural, 1983. Coleção Os Pensadores.

MAQUIAVEL, Nicolau. O Príncipe. São Paulo: Nova Cultural, 1999.

MARES, Carlos Frederico. Soberania do povo, poder do Estado. In: NOVAES, Adauto. (Org.). A crise do Estado-Naçáo. São Paulo: Cia das Letras, 2003.

MARINHEIRO, Vaguinaldo. Reino Unido caminha para desigualdade do século 19. Folha de São Paulo, São Paulo, p. A19, 7 jun. 2011.

MARX, Karl. O Capital: crítica da economia política. 9. ed. Livro 1. O processo de produção do capital. v. 1. Tradução Reginaldo Sant'Anna. São Paulo: Difel, 1984.

; ENGELS, Friedrich. A ideologia alemã (Feuerbach). Tradução de José Carlos Bruni e Marco Aurélio Nogueira. 6. ed. São Paulo: Hucitec, 1987. 
MURTA, Andrea. Renda de executivos dos EUA aumenta disparidade social. Folha de Sáo Paulo, São Paulo, p. A14, 5 jul. 2011.

OFFE, Claus. Dominação de classe e sistema político: sobre a seletividade das instituiçóes políticas. In: OFFE, Claus. Problemas estruturais do Estado capitalista. Tradução Bárbara Freitag. Rio de Janeiro: Tempo Brasileiro, 1984.

; WIESENTHAL, Helmut. Duas lógicas da ação coletiva: notas teóricas sobre a classe social e a forma de organização. In: OFFE, Claus. Problemas estruturais do Estado capitalista. Tradução Bárbara Freitag. Rio de Janeiro: Tempo Brasileiro, 1984.

PICÓ, Josep. Teorías sobre el Estado del Bienestar. 3. ed. Espanha: Siglo Veintiuno, 1999.

POCHMANN, Márcio. O emprego na globalização: a nova divisão internacional do trabalho e os caminhos que o Brasil escolheu. São Paulo: Boitempo, 2001.

SANTOS, Boaventura de Sousa. Reinventar a democracia: entre o pré-contratualismo e o póscontratualismo. In: HELLER, Agnes et al. A crise dos paradigmas em Ciências Sociais e os desafios para o século XXI. Rio de Janeiro: Contraponto, 1999.

SILVEIRA, Alair. As transformaçóes no mundo do trabalho e os desafios contemporâneos para a classe trabalhadora. Cuiabá, MT: ADUFMAT, 2008.

VASAPOLLO, Luciano. (Coord.) A Europa do capital: transformações do trabalho e competição global. Tradução de Maria de Jesus de Britto Leite. São Paulo: Xamã, 2004.

WEBER, Max. Economia e sociedade. Tradução de Régis Barbosa e Karen Elsabe Barbosa. Revisão Técnica de Gabriel Cohn. 5. ed. Brasília, DF: Editora da UnB, 1991.

Recebido em: 13.11.2011

Aprovado em: 18.02.2013

\section{Welfare State and social disaffiliation}

\section{Abstract}

Since the 80s, the world has gone through significant changes that not only sacralize the market and demonize the State, but produce an aggregate of social disaffiliates, as Robert Castel described. More than workers without jobs or even a perspective of getting one, they are "forgotten" men 
and women at the margin of society, as social destitutes with no place or citizen guarantees, in confrontation with a State increasingly more closed to its social responsibilities. The objective of this essay is, therefore, to reflect on the dynamic of social relations of capitalist production and the social costs of an army of forgotten people, immersed in the vulnerability and temporariness of everyday relations, marked by the hegemony of neo-liberalism, of post-modern culture, and of the restrictions to politics as an organic collective practice. The challenge in this scenario is to recover ways of bringing cohesion and solidarity to society and a socially responsible State.

Keywords: State of Social Well Being. Work society. Social disaffiliation. Collective solidarity. 